\title{
ARMING OR CHARMING: OBSEQUIUM AND DOMESTIC POLITICS IN ROMAN NORTH AFRICA ${ }^{1}$
}

\author{
M E A De Marre (University of South Africa)
}

\begin{abstract}
Scholarship to date has dealt mainly with the legal aspects of Roman marriage and its place within Roman society, most of which tends to focus on the disempowerment of women. This article, while not denying the disadvantages women suffered under these conditions, focusses on the mechanics by which women could achieve their aims within the boundaries of marriage and how the concept of obsequium could have been understood and implemented by both partners to the marriage contract.
\end{abstract}

In a scene from a fairly recent Hollywood production, Toula, the thirtyish daughter of a family of Greek immigrants living in Chicago, expresses to her parents her desire to go to college. ${ }^{2}$ Her wish is rejected out of hand by her father, who feels the only career for her should be marriage and babies. In a subsequent conversation with her mother, Toula says tearfully: "Ma, Dad is so stubborn. What he says, goes - 'the man is the head of the house'”. Her mother, played by the formidable Lainie Kazan, replies: "Let me tell you something, Toula. The man is the head, but the woman is the neck and she can turn the head a-n-y way she wants". The results of this issue bear out her confident assertion. This episode illustrates that even in patriarchal societies there are mechanisms used by women to reach their goals which are not reflected in law or even acknowledged in tradition.

In what follows I propose to look at similar situations from the provinces of Roman North Africa. ${ }^{3}$ I will deal only with the Romanized context of North Africa, since it is essentially this which provides the most evidence (literature, inscriptions and iconography). The evidence is varied in its presentation of marital tableaux, ranging from the formulaic style of inscriptions and iconography to the more individualised literary versions. The testimony referred to below has been gathered over a broad time span, from the first century AD to the sixth century, and including therefore also the evidence from the Christian period in Africa. This will serve to show that, despite changes in the definition of obsequium and in other aspects of the gender power balance, some elements of female empowerment remained essentially constant.

1 I would like to dedicate this short article to Dr Anton Powell, who visited us briefly as keynote speaker at the VI Classics Colloquium held at Unisa in February 2005, for his inspiring lectures and talks, and encouragement to take the road less travelled.

$2 \quad$ My Big Fat Greek Wedding (2001), produced by Rita Wilson, Tom Hanks and Gary Goetsman, IFC Films and Gold Circle Films.

3 Of course this will have a more general application to other parts of the Empire and other societies beyond the Mediterranean world. See for example the comparison by France (1993:92-93) between Ancient Greek and modern Fijian societies. 


\section{The legal and traditional principles of Roman marriage}

The Roman or Romanized family was organized on a patriarchal basis. By law, all Roman women were subject to tutela or guardianship of a paterfamilias, usually either their fathers, their husbands or their husbands' fathers, who in the early years of the Republic had complete authority over them, ${ }^{4}$ and whose permission had to be sought in the making of certain financial or legal transactions. ${ }^{5}$ The Roman tutela relaxed slightly in its practical effect from the first century $\mathrm{AD}$, since from this time it became more customary for women to remain in the control of their fathers rather than passing into the control of their husbands or their fathers-in-law upon marriage, an improvement for women which was achieved without defying the hierarchical and patriarchal construction of family authority (the principle of male potestas over the woman was not challenged, only which male would be holding potestas). ${ }^{6}$ It did conceivably give a woman more immediate freedom, as she did not live in the same house as her guardian, and the death of her father was also likely to occur before that of her husband, upon which she would be freed from tutela, unless her father appointed another guardian. ${ }^{7}$ From the first century AD onwards even being subject to such a tutor does not seem to have been of great significance in inhibiting a woman's freedom - Dixon goes so far as to say that by the end of the first century AD tutela was no more than a formal requirement, 'no more onerous than the need to collect witnesses to a signature'. 8

During the Empire the Romans came to project the ideal marriage as one without quarrel and where the partners had mutual respect and understanding, one which exhibited what the African writer and orator Apuleius calls concordia coniugii et multo amore (marital harmony and great love) [Apol. 92.4]. ${ }^{9}$ For the most part it is difficult to know where praise of harmonious marriages is merely serving convention, particularly when in a very standardised setting such as

4 Note for example the implications of the following, taken from a senatorial speech attributed to Lucius Valerius in 195 BC: Nunquam salvis suis exuitur servitus muliebris, et ipsae libertatatem quam viduitatas et orbitas facit detestantur. (Never, while their men survive, is feminine subjection shaken off, and they themselves abhor the freedom which the loss of husbands and fathers produces) [Liv. 34.7.12].

5 Tutela mulierum is discussed in most modern works on Roman women, but see especially Gardner 1986:5-22; Treggiari 1991:65-68; 381; Dixon 1992:43-46.

6 Such marriages with manus, according to the Institutiones [1.110-111] of Gaius, were abolished as well as falling out of use. The reasons for this change have not yet been satisfactorily explained, but see Crook (1967:103-104), and Pomeroy (1975:155), who feel that the decreased number of Roman men after the Punic Wars and the increase in women's wealth as a result were at least partly responsible. The agnatic line thus endeavoured to retain some control over the wealth of their daughters.

7 The argument that pre-industrial mortality made it possible for many sons to avoid having to live under the potestas of a father is voiced by Veyne (1978:37) - obviously the same advantages must have applied to daughters.

8 Dixon 1988:89.

9 Veyne (1978) sees the end of the competition for political honours (with the ascendancy of one man in politics) as crucial in the development of affectionate family relations among the Roman elite, since this caused men to look inward to their families rather than outward for a political career. Others, like Foucault (1985/6), ascribe a more sentimental ideal to the influence of Stoicism (e.g. Musonius Rufus speaks of the marriage of 'mutual devotion', the ideal of concordia). For the expression of the sentimental ideal, see also Dixon 1991. 
tombstones, and such evidence is not very useful in assessing the daily realities of the average marriage. Nevertheless it is important to note that there was a general awareness of such an ideal partnership in Roman societies, and, behind this, the consciousness that spouses often had conflicting interests which threatened the solidarity of the family unit. ${ }^{10}$

\section{Avenues of female power}

Despite the relaxation of tutela and the promulgation of images of marital concordia, Roman culture remained undoubtedly patriarchal. ${ }^{11}$ It was within these patriarchal limitations that women had to find ways to achieve their aims. Two avenues open to them will be examined here, that is to say, personal authority and manipulation, although it must be understood that both of these of course depended on the individual personality and character of the people most narrowly concerned. A woman's personal authority was influenced by a number of factors, for example the consequence of her natal home vis à vis that of her husband, ${ }^{12}$ the size of her dowry (and the possibility of divorce), and the opportunity of inheriting independently of her spouse even when not sui iuris, which would give her increased independence. The Roman wife was also able to claim recognition as the mistress of her husband's household, and this status was enhanced if she bore her husband children, especially sons. These empowering factors applied especially to older women, who under some or all of these conditions could have considerable authority in the household. ${ }^{14}$ In our Hollywood parallel we see this when Toula's mother confronts her husband Gus (on behalf of her daughter), reminding him of her contribution to their marriage and their family, and, at the end of her diatribe, stalking out of the room, completely confident that her husband will now acquiesce to their daughter's request. Examples of women wielding such authority from antiquity are not very plentiful, since our male-authored sources are naturally reluctant to give objective evidence on such matters. A typical male interpretation of such behaviour is the weak husband tied to his harridan wife's apron strings, familiar particularly from Roman satire, and of which we also have some examples from the Roman African context, which will be discussed below.

10 Dixon 1997:151.

11 The superiority of the husband, even in a marriage of concordia, is given in Apuleius' Metamorphoses [9.27], where the issue is the sharing of a young lover by the wife and husband: Nam et ipse semper cum mea coniuge tam concorditer vixi, ut ex secta prudentium eadem nobis ambobus placerent. Sed nec aequitas ipsa patitur habere plus auctoritatis uxorem quam maritum (You see, I have always lived in such harmony with my spouse that, in accordance with the teachings of the wise, we both have the same tastes. But the principle of equity does not permit a wife to have greater right of ownership than her husband).

E.g. Porcia, the daughter of Cato, who reportedly saw herself in her marriage to Brutus as an equal partner in his prosperity and troubles [Plut. Brut. 13]; Agrippina the Younger, against Nero, defining herself as Germanici filia [Tac. Ann.13.14.3]. Apuleius himself cites the Republican exempla of women who were dowered by the public treasury and brought with them the 'honour of their houses and the wealth of the state' (portantes gloriam domesticam, pecuniam publicam) [Apol. 18.9].

Dixon 1985:168; Hopkins 1983:90; Treggiari 1991:210.

14

To illustrate that sometimes wives could dominate without these advantages, see the portrayal of the Plautine character Demaenatus, who despite having married his wife cum manu, had little say over her dowry or over her. 
Manipulation is the more covert technique whereby the confrontation with male authority is averted altogether, and in which the wife either uses her knowledge of her husband to get what she wants, or employs techniques like prevarication and evasion. In the case of Toula's parents, her mother's conspiratorial words: "We must let Gus think this was his idea” tells us all we need to know. Manipulation also has less to do with age - one asks oneself if Pliny's Calpurnia was quite as guileless as Pliny seems to think!

\section{Obsequium}

It is against the background of this balance of male and female power that the precise nature of obsequium, a term commonly used in the context of marital relationships, is debated by modern scholars, particularly since it was still used when it had become customary for women to remain in the power of their fathers rather than their husbands. ${ }^{16}$ Deriving from the verb obsequi, obsequium is traditionally translated as 'obedience' or 'compliance' and entails, at least to some extent, to yield or submit to the will of another. The word is also used in other associations, for example in the relations of freedmen and their masters, of emperor and subject, and in Roman elegy, where it is the lover who shows obsequium to his mistress. In all of these cases an element of subservience is understood as playing a part, but we may also note that obsequium in these cases was used as a type of quid pro quo, almost as a tool, so that the individual expressing obsequium may get his or her reward. It gives no indication of the mind set of the person who may be described as obsequens and in many cases obsequium may be proven to be mere lip service.

The question here is essentially to what extent obsequium within marriage carried a connotation of subservience, whether it was understood in the same way by both sexes, and finally how it was implemented in the realities of everyday life.

\section{The traditional male view of marital obsequium}

A number of Roman African epitaphs mention the word obsequium, although it is as well to note that tombstones often tell us at least as much about the commemorator(s) as about the deceased, since the former were unlikely to include information which would not reflect well on themselves. It is likely, therefore, that in the following three examples where the husbands are the commemorators obsequium is intended to mean 'submissive' or at least 'compliant', since the association of ideas makes this meaning quite clear. On her tombstone Victorina was said to be pudicissima obsequentissima moribus excellentisima (sic) pia su[o]r[u]m am[a]n[t]issima (most chaste and compliant in her behaviour; of exceptional dutifulness, a woman loving to her

15

Pliny, Ep. 4.19. It is generally thought that seniority in years enhanced the husband's superiority and dominance over a young wife (Saller 1987), but it must be remembered that our perceptions are based on the products of the male mind.

16 Marital obsequium debated by modern scholars: Williams 1958: 24-25; Treggiari 1991:238-241.

17 Obsequium as lip service: e.g. Juvenal's caricature of the patron-client relationship [Sat. 1]; Pliny, Ep. 7.24.3; Artotrogus in Plautus, Mil. Glor., etc. 
own). ${ }^{18}$ The use of pia, arguably the word most often used for deceased women as part of the ideal of Roman womanhood, also reinforces the idea of submission to male authority. ${ }^{19}$ At Caesarea in Mauretania Caesarensis, the mention of obsequium is reinforced by a deceased wife's 'eagerness to please' (co niugis opsequio (sic) semper placuis(s)e), and in the following example from Lambaesis it is included in a list of other traditional female virtues, and given climactic emphasis by being placed at the end:

Dis manibus sacrum Cl(audiae) Successae Cn(eius) Badusius Leo coniugi
humanissimae sanctissimae fidelissimae obsequentissimae vix(it) an(nis) XXXVII
b(ene) m(erenti) d(e se) f(ecit)
Consecrated to the spirits of the departed. Gnaeus Badusius Leo set this up for his wife,
Claudia Successa, most humane, most virtuous, most faithful and most compliant. She
lived 37 years. She was worthy of this. [CIL 8.3531]

Clearly these husbands considered wifely obsequium a positive reflection on themselves as much as on their wives. But even if such feminine virtues were perceived to exist in the eyes of these husbands and we are unfortunately presented with only one side of the picture, this is of course no guarantee that their wives were disempowered doormats, as will be shown below.

\section{Other interpretations of obsequium}

The above examples present a traditional, simplistic male view of obsequium, but other sources reveal that a more complex meaning can be given to the term, also within the marital context. In one inscription [CIL 8.5804] from Sigus, the term obsequium seems to be applicable to both Iulia Spesina and to her commemorator husband, since she 'surpassed' her husband in 'dutiful compliance' (obsequio pietatis superasti), implying that he also practised obsequium towards her. Also in the Apologia [100.3], a defence speech by Apuleius, the author refers to himself as obsequentissimum maritum (which we may translate as 'most devoted husband'), the word is used more in this sense of dedication and fidelity. Apuleius is not implying any subservience on his part towards his wife, Aemilia Pudentilla, and is in fact using what Hunink terms 'a fine piece of self-praise' here, since he is contrasting his own exclusion (as an exemplary husband)

18

19

20

21

Djebel Azza (near Kef), CIL 8.16286 = ILT 1665.

Treggiari 1991:242. See also Saller 1988 and 1991 for the expectation of pietas from all family members towards one another. A North African example of filial obsequium in CIL 8.9519.

CIL 8.21179. See also another example, Ennia Fructuosa, from Cirta [CIL 8.7705]: cer/tae pudicitiae bonaque obse/quio laudanda matrona/ (of undoubted modesty and a matron worthy of praise for her compliance).

But when one husband from Sigus [CIL 8.5834] calls his late wife Pomponia Fortunata generally 'superior to her husband' (superusti [mar] itu(m)) on her tombstone, this is probably not meant to be taken literally, and in all likelihood he would have been most offended had anyone else made such a statement. Moreover, superiority in particular qualities in a wife did not equal a position of inferiority on the part of the husband. From Henchir Haj Abid, near Ammaedara, a double epitaph erected by Claudius Ianuarianus distributes praise evenly between himself and his late wife, who 'vied with [one another] in dutifulness, virtue, frugality and love' (certavi tecum coniunx pietate virtute frugalitate et amore) [ILT 489; CLE 2299; ILAfric 175]. 
from Pudentilla's will with the inclusion of her inimicissimum filium, her most hostile son. ${ }^{22}$ Since the concept can be applied to both men and women within marriage, the word obsequium can also be understood as an indication of the devotion and self sacrifice of one partner in a marriage rather than carrying the connotation of subservience.

\section{Deference in demeanour only}

For the perspective of women on this issue we have of course no first hand evidence, since, apart from Perpetua's account of her martyrdom, there are no women's writings from Roman Africa. Nevertheless, in one particular instance our male-authored evidence does present a clue. In the Apologia Apuleius sketches his wife Pudentilla as a model of traditional Roman virtues: she is chaste, modest, a good mother despite her ungrateful offspring, and generally of a blameless character. ${ }^{23}$ But Apuleius also relates that as a widow Pudentilla had to use a certain amount of guile and manipulation to achieve her aims in one instance. ${ }^{24}$ Despite her father-in-law's attempts to make her marry his second son [Apol. 68.5-6], Pudentilla outwitted him by prevaricating and avoiding the marriage until the death of her father-in-law made this no longer necessary. In doing so she both preserved her sons' inheritance of their grandfather's estate, and was later able to marry the man of her choice, Apuleius. Hunink has already pointed out the Penelope-like image that Apuleius cultivates here. ${ }^{25}$ It is very much an ideal image of patience and loyalty to her children, but also one where a woman survives by manipulation of events rather than by direct confrontation with authority.

The responsibility of marital harmony was traditionally laid at the wife's door, as Tacitus notes in his description of the marriage between Agricola and Domitia Decidiana, and the type of manoeuvring illustrated above shows that women could appear superficially submissive to male authority, but get their own way just the same. ${ }^{26}$ By avoiding confrontation and by using diplomacy, women could preserve the harmony of marital and other family relationships and still protect their own interests.

In the context of Roman elegy we are familiar with the assumption of the inferior position as a tool of manipulation to get what you want. ${ }^{27}$ It has however been noted that the lover's

22

23 Hunink 1997 II:243.

23 Descriptive of Pudentilla, e.g. virtutibus suis [66.2]; mulieri amanti [67.4]; mulier sancte pudica, tot annis vivitatis sine culpa [69.2]; tam gravis feminae [71.2]; virtutium eius dotes [73.7]; ingenium placidissimum [77.6]; feminam sanctissimam et pudicissimam [78.1].

24

After the death of her first husband a guardian was appointed for Pudentilla by her husband's will [Apol. 101.6], but he does not seem to have been an impediment to her autonomy, although he authorized her financial transactions [Apol. 101.7].

25

26 Hunink 1997 II:181.

Vixeruntque mira concordia, per mutuam caritatem et in vicem se anteponendo, nisi quod in bona uxore tant maior laus, quanto in mala plus culpae est (They lived in rare accord, maintained by mutual affection and unselfishness; in such a partnership, however, a good wife deserves more than half the praise, just as a bad one deserves more than half the blame) [Tac., Agric. 6.1].

27

For obsequium as practised by men, and as an instrument to 'get what you want', see Propertius 1.8 a and b; 1.10.21-28; 2.23.23-24; Tibullus 1.4.39-56; Ovid, Ars Amat. 2.177-202. For discussion, see Greene 1998:63. 
obsequium and servitium are singularly unsuccessful. ${ }^{28}$ The poet-lover fails in achieving his aim of 'getting the girl', even if his obsequium has some success in its role as a standard part in the writing of elegiac poetry. ${ }^{29}$ Women in the real world are very likely to have had a higher success rate with their long practice of obsequium and marital politics than their male elegiac counterparts.

\section{Female authority}

As mentioned previously, the other avenue of female empowerment was that of personal authority, and that was exercised chiefly in a woman's own household. Sallust [Bell. Iug. 80.6-7] spoke with disdain of the polygamous practice among the Mauri, in which none of the wives had the status accorded to a single partner, as in Roman marriages. There are a number of funerary inscriptions from North Africa mentioning the woman's honoured role as custos/conservatrix of the home, ${ }^{30}$ and as excellent, even prolific, mothers. ${ }^{31}$ As a contrast we may compare her status also with the position of the concubine, for example in the case of Augustine, who had a ten year relationship with a woman who bore him a son, but who, in all his writings, is never once mentioned by name.

Conversely, wives who were perceived to have too much to say in the household were heavily criticized. Luxorius, an African poet active at the turn of the sixth century, devotes an epigram to the quarrelsome nature of Catucia, whose husband, according to the poet, never got a word in [Epigr. 52]. Second marriages for women (divorcées or widows) also overturned the traditional implementation of concordia and female subordination. Apuleius, in explaining why widows offer large dowries, describes the widow or divorced woman as 'far from tractable to your wishes' (certe tibi ad quae velis minime docilis) [Apol. 92.8]. Although Apuleius is at pains to point out that he received but a small dowry when he married the wealthy widow Pudentilla [Apol. 67.4; 92.3], there is a plethora of evidence from the rest of the Roman world that a rich woman could buy a compliant husband. ${ }^{32}$ This mundus inversus is sketched by the sixth century poet Corippus. He describes how, at a time when a plague took many lives, women accrued much wealth by inheritance, and men were keen to marry 'powerful widows' (viduas potentes) while maidens were left on the shelf [Ioh. 3.369-375]. Female authority is also implicit in the fourth century tomb paintings of Aelia Arisuth and her husband Aelius Ma[gnus or -ximus], son of Iarathanus, at Tripolitanian Gargàresh, since the portrait of Aelia is much more lavishly

28

While the elegiac parallel is based on an inversion of gender roles, its focus, as Wyke (2002:44) has argued, is the new role for the lover rather than a more powerful role for the mistress. Only Propertius's fourth book and Ovid's Heroides, for example, give women a voice.

30

CIL 8.647; 7384 (= ILAlg II, 1185); CIL 8.21300; AE 1919, 46 (= ILAlg I, 2242).

For example: good mothers at $A E$ 1995, 1793; CIL 8.11294. Idealisation of fertility: fecunda subolis [CIL 8.26673]; fecundae tecusae rarissimae [CIL 8.4692]; quae fecundo par/tu numerosa [AE 1919, 46]

32

Treggiari 1991:330. Compare Martial's remark on why he does not want a rich wife, since he does not want a husband for a wife [Epigr. 8.12] 
executed and shows her holding a scroll, whereas that of her husband is smaller, inferior in quality, and shows him lying idly beneath a tree.

To conclude the pagan section, it would appear that obsequium need not necessarily have meant the subservience of one partner, even though it is likely that there was an element of this in husbands' understanding and use of wifely obsequium. At the same time, women, while outwardly performing the traditional female role of duty and obsequium towards male authority figures, had techniques of getting their own way, either through manipulation or simply by using their own personal authority.

\section{Christian influences on marital relations}

The influence of Christian mores and the Christian Church on the position of women in Roman antiquity has been much discussed by modern authors, and is too complex and lengthy to review here. Suffice it to say that Christ's own attitude towards women in the New Testament did not have as far reaching an influence as the teachings of Paul, which were undeniably less favourable and a reinforcement via Judaism of the most conservative Roman attitudes. ${ }^{35}$ That the meaning of obsequium takes on an extra significance in Christian teaching is abundantly evident from Augustine's writings, and certainly now it became more emphatically focussed on obedience. In his sermons and elsewhere Augustine repeatedly remarks that the husband is the master (dominus) and his wife the obedient servant (ancilla), a view which he bases on the terms of the marriage contract and on Biblical texts such as the letters of Paul [1 Cor. 11.3]. ${ }^{37}$ This view, Augustine claims, was not rooted in a belief that women were inferior in mind and soul [Conf. 13.32], but was a way of keeping order in the family.

A greater emphasis on women's obedience was not always to the benefit of men, however, as the new role of the Church presented its own complications for the married couple. Women sometimes found themselves divided between their allegiance to God and the Church on the one hand, and their husbands on the other. As bishop, Augustine was often confronted with the conflict between women's family obligations and their calling to follow Christ, and failed to

33

34

Romanelli (1922:414) is particularly scathing about the inferior paintwork of the second and smaller niche.

Some recent scholarship on women and Christianity: Coon, L., Haldane, K. and Sommer, E. 1990. That gentle strength. Historical perspectives on women in Christianity. Charlottesville: University of Virginia Press; Clark, E. A. 1983. Women in the early church. Wilmington: Michael Glazier; Eyben, E. 1992. Vrouwen in de Grieks-Romeinse Oudheid en het vroege Christendom. Leuven: Uitgeverij Acco; Sawyer, D.F. 1996. Women and religion in the first Christian centuries. London and New York: Routledge; Scholer, D.M. (ed.). 1993. Women in early Christianity. New York: Garland.

35

36

37

Christianity did provide some benefits for women, but these applied more to those who did not wish to marry and to widows.

alterius regentis obsequentis amicalis quaedam et germana coniunctio (a kind of friendly and genuine union of the one ruling and the other obeying) [De Bono Coniug. 1.1]. The development of Augustine's thoughts on marriage is discussed by Berrouard (1972).

Serm. 37.7; 332.4; De Mor. Eccl. Cath. 1.30.63; De Bono Coniug. 6.6; De Coniug. Adult. 2.8.7f; Ad Gen. Ad Litt. 11.37.50; Serm. 332.4.4; 392.4. Arguments for the complete power of the paterfamilias also given at Civ. Dei 19.16. 
reach a perfectly consistent attitude on this issue. When Ecdicia, a fourth century matron in his congregation, felt a calling to celibacy, she was reprimanded by Augustine for not showing the necessary obsequium towards her husband, who had not desired continence and who furthermore objected to his wife giving her money to monks [Ep. 262]. ${ }^{38}$ Augustine felt that her calling did not free her from her family obligations. In the case of Perpetua, however, who had been martyred at Carthage more than a century ago, he took the opposite view, praising both her and her slave girl Felicitas for putting their martyrdom before their families [Serm. 281]. ${ }^{40}$ It is significant, however, that these women were removed from his own reality by time. There are some further inconsistencies in Augustine's thoughts, of which he, a man of his time, was probably completely unaware. Augustine was for example rather critical of the practice of giving wives the management of household finances [Ep. 130.2.5-3.8]. Popular opinion held such wives to be generally tightfisted so that husbands who wanted to give money to the poor had to hide the fact that they did so from their wives [De Serm. Dom. in M. 2.2.7]. Augustine's message in such cases was that no true Christian wife would begrudge money to the poor, while practising deceit would not earn God's favour!

But female obedience, whether to God or husband, was never questioned, at least not by men. The fact that Augustine's mother Monica chided the other wives of Thagaste for complaining about the beatings they received at the hands of their husbands would seem to indicate that for these women there was some resistance to the idea of total obedience. ${ }^{41}$ The other wives were also astounded that Monica adjured them to consider themselves as slaves to their husbands, but she further advised them 'speaking as if in jest but offering serious advice' (veluti per iocum graviter admonens) to handle their husbands with the techniques she herself employed, which are described as follows by Augustine:

38 There are other instances where wives were more successful in persuading their husbands to live in continence, e.g. Maxima and Martianus, mentioned by Victor Vitensis [Hist. Persec. 1.30-31], and Melania the Younger and her husband Pinianus.

Augustine's letters to two other noble ladies in Rome, Juliana and the widow Proba, also concern the issue of continence [Ep. 130 and De Bono Vid.], and in general Augustine is of the opinion that continence within marriage is not for the average man [De Bono Coniug. 13.15]. Augustine also argued that a married woman could not do as she liked with her own possessions, since she herself belonged to the head, her husband (Facio quod volo de meo, cum et ipsa non sit sua sed capitis sui, hoc est viri sui [Ep. 262.7].

40

Perpetua's husband is singularly absent from the account in the Passio, even though it is mentioned that she is married; her refusal to heed the wishes of her father is given some prominence in the narrative [Passio SS. Perpetuae et Felicitatis 5.2].

Wife-beating was clearly not uncommon, and Augustine's letters cite other examples, such as a man who disciplined his wife for looking out of the window, since he interpreted this as a prelude to dalliance [Ep. 246.2]. Wife-beating was never considered as grounds for divorce in antiquity, but in AD 548 under Justinian a heavy financial penalty was introduced for offenders [Nov. Iust. 127.4]. 
sed noverat haec non resistere irato viro, non tantum facto, sed ne verbo quidem. Iam vero refractum et quietum cim opportunum viderat, rationem facti sui reddebat, si forte ille inconsideratius commotus fuerat.

She knew that an angry husband should not be opposed, not merely by anything she did, but even by a word. Once she saw that he had become calm and quiet, and that the occasion was opportune, she would explain the reason for her action, in case perhaps he had reacted without sufficient consideration. [Conf. 9.9]

Of course Augustine's perceptions in the Confessions were seen through the prism of his conversion - we may imagine the basis of Monica's approach to lie in the words spoken by the character of Andromache in Euripides' Troades [642-51]: 'I knew when to have my way and

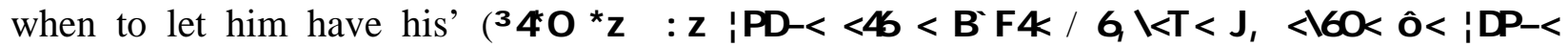
B" DAX 4 4). As a consequence of her wisdom, Augustine tells us, Monica did not bear the marks of beating like the other wives. Once again, therefore, the spirit of the undertaking was undermined by the way in which women were inclined to understand such 'obedience'. Even when a woman like Monica herself advocated total obedience and acknowledged and accepted male authority, it did not prevent her from getting her own way in a diplomatic and nonconfrontational manner.

Augustine ascribed the success of his mother Monica in obeying her husband to her love for God:

et in hoc adiuvabas eam, ut superaret virum, cui melior serviebat, quia et in hoc tibi utique id iubenti serviebat.

And in this endeavour you helped her to gain victory over her husband. His moral superior, she rendered obedient service to him, for in this matter she was being obedient to your authority. [Conf. 1.11]

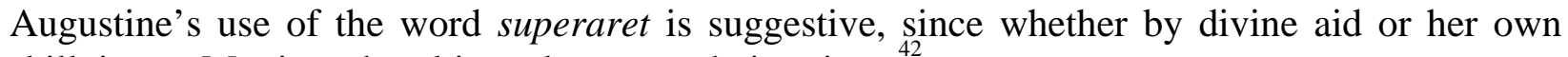
skill, it was Monica who ultimately emerged victorious.

\section{Conclusion}

Generally discussions of Roman marriage focus mainly on the disadvantages suffered by women within that context, and of course it cannot be denied that women were not granted the same opportunities and privileges as men. However, the above instances are rarely revealed exempla of a pattern of marital politics which stretches across patriarchal societies, showing how women could and did achieve at least some of their aims within the limitations of the patriarchal system. Here we have women who emerged victorious, even in cases of apparent extreme male dominance such as Monica's physically abusive husband, and so, to adapt a famous phrase from Horace, it was possible that uxor capta ferum maritum cepit.

42

It is Augustine's relationship with Monica which is probably the basis for Brown's description of Augustine's congregation as a small community of 'tightly-knit families in which the mother played a dominant role' (1967:247). Physical dominance was therefore not always the ultimate victor. 


\section{BIBLIOGRAPHY}

Texts and translations:

Apuleius, Apologia in Pro se de Magia (Apologia), Vols. I and II, edited by Vincent Hunink, (Amsterdam: Gieben, 1997). English translation by H E Butler: The Apologia and Florida of Apuleius of Madaura. Westport Connecticut: Greenwood Press, 1970.

Metamorphoses edited and translated by J A Hanson (Cambridge: Harvard University Press/London: Heinemann: Loeb Classical Library, 1989).

Augustine, Confessions. In Goold, G P (ed) St. Augustine's Confessions. Volumes I and II (Cambridge: Harvard University Press/London: Heinemann: Loeb Classical Library, 1977). English translation by H. Chadwick: Saint Augustine. Confessions (Oxford/New York: Oxford University Press, 1991).

Euripides, Troades. In Euripides: Trojan Women, translation with commentary by S H Barlow. Warminster: Aris \& Phillips Ltd, 1986.

Livy, $A b$ Urbe Condita, edited and translated by E T Sage et al (Cambridge: Harvard University Press/London: Heinemann: Loeb Classical Library, 1919-).

Tacitus, Dialogus, Agricola and Germania, edited by W H Fyfe. Oxford: Clarendon Press, 1908. English translation by $\mathrm{H}$. Mattingly, revised by $\mathrm{S} \mathrm{A}$ Hanford, The Agricola and the Germania. Harmondsworth: Penguin Books, 1970.

Secondary literature:

Berrouard, M-F 1972. Saint Augustin et l'indissolubilité du mariage: l'évolution de sa pensée. Studia Patristica, 11 (= Texte und Untersuchungen 108), 291-306.

Bremmer, J N 1994. Pauper or patroness: the widow in the early Christian Church. In Van den Bosch, L P \& Bremmer, J N (eds), Between poverty and the pyre: moments in the history of widowhood, ch. 3. New York: Routledge.

Brown, P 1967. Augustine of Hippo: a biography. Berkeley: California University Press.

Crook, J 1967. Law and life of Rome. Ithaca: Cornell University Press.

Dixon, S 1985. Polybius on Roman women and property. AJP 106, 147-170.

Dixon, S 1988. The Roman mother. London: University of Oklahoma Press.

Dixon, S 1991. The sentimental ideal of the Roman family. In Rawson, B. (ed), Marriage, divorce and Children in Ancient Rome, 99-113. Oxford: Clarendon Press

Dixon, S 1997. Conflict in the Roman family. In Rawson, B and Weaver, P. (eds), The Roman family in Italy. Status, sentiment, space, 149-167. Oxford: Clarendon Press.

Fick, N 1992. Mariage d'argent, mariage d'amour: la magie du mariage d'Apuleé. VL 125, 29-46.

Foucault, M 1985/6. The history of sexuality. New York: Vintage Books, volumes 2 and 3.

France, P 1993. Greek as a treat: an introduction to the Classics. London: BBC Books.

Gardner, J F 1986. Women in Roman law and society. London: Croom Helm.

Greene, E 1998. The erotics of domination. Male desire and the mistress in Latin love poetry. Baltimore: Johns Hopkins University Press.

Hopkins, K 1983. Death and renewal, sociological studies in Roman history. Cambridge: Cambridge University Press.

Lee-Stecum, P 1998. Powerplay in Tibullus. Reading Elegies Book One. Cambridge: Cambridge University Press.

Pomeroy, S B 1975. Goddesses, whores, wives and slaves. New York: Schocken Books.

Romanelli, P 1922. Tomba romana con affreschi del IV secolo dopo cristo nella regione di Gargàresh. In Romanelli, P 1981. In Africa e a Roma: scripta minora selecta, Rome, 405-427. L’Erma di Bretschneider.

Saller, R 1987. Men’s age at marriage and its consequences in the Roman family. CP 82, 21-34.

Saller, R 1988. Pietas, obligation and authority in the Roman family. In Kneiss, P \& Laseman, V (eds) Alte Geschichte und Wissenshaftsgeschichte. Festschrift für Karl Christ zum 65. Geburtstag, 393-410. Darmstadt: Wissenschaftliche Buchgesellschaft. 
Saller, R 1991. Corporal punishment, authority and obedience in the Roman household. In Rawson, B (ed), Marriage, divorce and Children in Ancient Rome, 144-165. Oxford: Clarendon Press.

Shaw, B D 1987. The family in late Antiquity: the experience of Augustine. P\&P 115, 3-51.

Treggiari, S 1991. Roman marriage. Iusti coniuges from the time of Cicero to the time of Ulpian. Oxford: Clarendon Press.

Veyne, P 1978. La famille et l'amour sous le haut-empire romain. Annales (ESC) 33, 35-63.

Williams, G 1958. Some aspects of Roman marriage ceremonies and ideals. JRS 48, 16-29.

Wyke, M 2002. The Roman mistress: ancient and modern representations. Oxford: Oxford University Press. 